\title{
Fungiculture : Sistem Pertanian Fungi oleh Serangga
}

\author{
Fungiculture : Insect Farming Fungi
}

Ivan Permana Putra

Divisi Mikologi, Departemen Biologi, FMIPA, IPB University, Corespondent email: ivanpermanaputra@apps.ipb.ac.id

Received: 11 June 2020| Accepted: 03 July 2020 | Published: 20 July 2020

\begin{abstract}
Abstrak. Fungi dan serangga merupakan kelompok organisme dengan jumlah spesies yang tergolong paling banyak di dunia. Hal ini membuat peluang interaksi antara kedua kingdom ini menjadi sangat tinggi. Diantara berbagai macam bentuk asosiasi tersebut, hubungan mutualistik berupa mekanisme 'pertanian' fungi oleh serangga merupakan salah satu hal yang menakjubkan hingga saat ini. Interaksi ini diketahui telah ada selama lebih dari puluhan juta tahun. Model simbiosis mutualisme ini berlangsung resiprokal dengan aspek kebermanfaatan diantara keduanya terkait nutrisi, perlindungan, dan penyebaran propagul. Berbagai kelompok serangga seperti rayap, semut, dan kumbang telah dikenal lama sebagai partner dari mikobion yang umumnya merupakan filum Ascomycota dan Basidiomycota. Rayap, semut, dan kumbang diketahui memiliki jalur evolusi kemampuan 'bertani' yang berbeda, namun semuanya dipengaruhi oleh kondisi lingkungan. Serangga-serangga tersebut memiliki mekanisme 'pertanian' yang unik, mulai dari persiapan, perawatan, hingga pemanenan fungi. Selain itu, keberlanjutan simbiosis yang terbentuk sangat begantung pada aspek manfaat yang diterima oleh masing-masing simbion.
\end{abstract}

Kata kunci: Fungi, Serangga, Simbiosis, Mutualisme, Bertani.

Abstract. Fungi and insects are group of organisms with a huge number of species in the world. This condition facilitating the high chances of interaction between the two kingdoms. Among the several forms of association, the mutualistic relationship in the form of the mechanism of fungus-farming insects is one of the amazing things till time. This interaction is known to have existed since more than dozens millions of years. This symbiotic mutualism model is a reciprocal aspects of the benefits between fungi and insects related to nutrition, protection, and propagation dispersal. Various types of insects such as termites, ants, and beetles have long been known as partners of the mycobion which is generally consist of Ascomycota and Basidiomycota. Termites, ants and beetles are known to have different evolutionary pathway of farming abilities, but they are influenced by environmental condition. Those insects pose unique farming mechanism, including preparation, maintenance, and harvesting fungi. In addition, the sustainability of the symbiosis formed is depend on the aspect of the benefits acquired by each symbiont. Keyword: Fungi, Insects, Symbiosis, Mutualism, Farming.

\section{PENDAHULUAN}

Serangga diketahui mampu untuk mengelola simbion funginya yang dianalogikan sebagai kegiatan 'bertani' fungi. Kemampuan 'bertani' fungi ini dihipotesiskan telah berlangsung sejak 40-60 juta tahun yang lalu, jauh sebelum manusia berpindah dari hidup nomaden dan memulai sistem pertanian (Mueller dan Gerardo, 2002; Mueller et al., 2005). Seperti halnya manusia, serangga kemudian mulai bergantung kepada hasil 'pertaniannya' dan mengembangkan strategi domestikasi fungi yang meliputi : menyiapkan substrat dan inokulum, inokulasi, pengontrolan dan optimalisasi pertumbuhan fungi, proteksi dari parasit dan penyakit, hingga melakukan pemanenan (Farrell et al.,2001; Aanen et al., 2002; Currie et al., 2003; Mueller et al., 2005). Disisi lain, fungi mendapatkan proteksi dan tempat hidup yang sesuai. Pada banyak fungi yang telah menjadi simbion obligat, mekanisme pemencaran sporanya hanya bergantung pada serangga. 
Tiga kelompok utama serangga yang telah banyak dipelajari mengenai kemampuan bertani funginya adalah rayap, semut, dan kumbang. Rayap diketahui memiliki spektrum interaksi yang sempit (Mueller et al., 2005) karena hanya mendomestikasi fungi Termitomyces dari filum Basidiomycota. Jamur ini membentuk tubuh buah di luar sarang rayap dan oleh sebagian besar masyarakat Indonesia dikenal sebagai jamur rayap, jamur barat (Jawa), atau supa bulan (Sunda). Jamur ini merupakan kelompok jamur edibel yang mudah ditemui di alam (Putra et al., 2019; Putra, 2020). Jika digali sedalam puluhan sentimeter, tangkai dari jamur ini akan ditemukan terhubung ke sarang rayap. Sementara itu, semut dan kumbang memiliki spektrum asosiasi yang lebih beragam (Mueller et al., 2005) dengan fungi dari kelompok Ascomycota, hampir semua kelompok Basidiomycota, dan sebagian kecil fungi bermitospora (dulunya dikenal sebagai Deuteromycota). Serangga diketahui mencari (foraging) berbagai macam bahan organik seperti daun dan ranting untuk dibawa ke lokasi 'kebun' fungi yang merupakan bagian dari sarangnya. Atau pada beberapa kasus, serangga seperti kumbang Ambrosia sengaja melubangi pohon dan meletakkan miselium (bentuk jamak dari hifa) pada tempat tersebut. Fungi kemudian mengkonversi bahan organik berbasis karbon tinggi yang telah disiapkan oleh serangga, menjadi bentuk yang memiliki nitrogen yang tinggi dan bercampur dengan sebagian miseliumnya. Miselium fungi juga dilaporkan memiliki nilai nutrisi yang tinggi (Chang dan Miles, 2004) dan dikonsumsi oleh berbagai jenis hewan (Merritt, 2010). Sebagian dari fungi yang 'ditumbuhkan' oleh serangga kemudian dimanfaatkan oleh serangga untuk pertumbuhan dan perkembangannya. Namun mekanisme pengaturan bagian mana dari koloni fungi yang dikonsumsi masih belum bisa dijelaskan.

Simbiosis mutualistik ini menjadi lebih menarik karena baik fungi maupun serangga keduanya merupakan organisme heterotrof. Sebagai host, tentunya serangga mendominasi interaksi ini terutama dalam pengaturan tugas dan manajemen sumberdaya. Beberapa serangga diketahui mengembangkan kemampuan pembagian tugas untuk 'mengurus' kebun funginya sebagai hasil dari evolusi sejak jutaan tahun yang lalu (Bourke, 2005). Sebagai organisme sosial, strategi ini merupakan bagian yang tidak terpisahkan dari mekanisme pengaturan di dalam satu koloni ataupun interaksinya dengan koloni yang lain dalam hal 'bertani' fungi (Foster dan Wenseleers, 2006). Serangga pengkultivasi fungi diketahui melakukan 'pertanian' sistem monokultur dengan mekanisme yang berbeda pada tiap host nya. Di Indonesia sendiri, topik penelitian seperti ini masih belum banyak ditemukan laporannya. Salah satu laporan terkait interaksi rayap dengan fungi dan mekanisme pembentukan sarang rayap hanya dilaporkan oleh Anwar et al., (2020). Oleh karena itu, dengan adanya ulasan ini, diharapkan semakin banyak penelitian dan laporan mengenai kultivasi fungi oleh serangga asal Indonesia untuk mengungkap hal-hal yang belum pernah dilaporkan sebelumnya.

\section{METODE}

Informasi yang digunakaan dalam penulisan ulasan ini diperoleh melalui hasil penelitian sendiri dan juga studi pustaka. Penelusuran pustaka online dilakukan melalui laman akademik yang menyediakan jurnal ilmiah gratis dan berbayar seperti sciencedirect, researchgate, googlescholar, wiley online library dan lain-lain. Informasi dikumpulkan dengan menggunakan kata kunci yang berhubungan dengan penulisan ulasan ini misalnya fungiculture, fungiculture origin, insect farming fungi, insect-fungi symbiosis, fungi cultivar transmission, dan lain sebagainya. Selanjutnya informasi yang diperoleh kemudian dianalisis dan disintesis, serta 
disusun untuk menjelaskan pandangan penulis terkait asal dan evolusi sistem pertanian fungi oleh serangga, mekanisme fungiculture pada serangga yang terlibat, dan manajemen 'kebun fungi' oleh serangga.

\section{HASIL DAN PEMBAHASAN}

\section{Asal-usul dan Evolusi Fungiculture Pada Serangga}

Frekuensi interaksi fungi dan serangga yang tinggi sebagai konsekuensi dari jumlah ragam yang sangat banyak diantara keduanya telah berlangsung dalam waktu yang lama. Interaksi yang terjadi beragam, dari komensalisme, parasitisme, hingga mutualisme. Evolusi simbiosis mutualisme mengharuskan asosiasi yang bersifat resiprokal dimana masing-masing organisme menyediakan servis yang tidak dimiliki oleh rekannya. Hal ini merupakan kunci dari terciptanya pola hidup mutualistik yang stabil. Simbiosis mutualisme yang terjadi antara fungi dan serangga menjadi lebih menarik karena keduanya merupakan organisme non autotrof.

Rayap, kumbang, dan semut diketahui memiliki jalur evolusi yang berbeda dalam pengembangan strategi 'bertani' fungi (Mueller dan Gerardo, 2002; Schultz dan Brady, 2008). Evolusi fungiculture pada rayap kemungkinan terjadi pada lebih dari satu kelompok sehingga terjadi koevolusi bersama. Pada rayap, fungi diduga pada awalnya adalah sumber makanan untuk koloninya. Hifa dan miselium fungi merupakan sumber nutrisi bagi banyak hewan. Hewan yang memakan fungi dikenal juga dengan istilah mikofagi atau fungivora. Kemampuan mendomestikasi muncul ketika rayap mampu untuk mengatur pertumbuhan fungi (Aanen et al., 2002; Mueller et al., 2005). Namun mekanisme pengontrolan tersebut masih belum jelas hingga saat ini. Karena kemampuannya ini, beberapa jenis rayap non 'petani' fungi juga datang dan melakukan interaksi. Hal ini dipandang sebagai bentuk mekanisme koevolusi diantara dua kelompok rayap tersebut meskipun bentuk interaksi dan peran dari rayap non petani masih belum bisa dijelaskan (Rouland-Lefevre, 2000). Disisi lain, nenek moyang fungi yang berasosiasi pertama kali dengan rayap dihipotesiskan memanfaatkan rayap untuk menyebarkan sporanya meskipun harus menyediakan 'upeti' berupa biomassanya yang dikonsumsi oleh rayap sebagai konsekuensi dari simbiosis yang terbentuk. Sebanyak 330 spesies rayap diketahui memiliki kemampuan fungiculture (Eggleton, 2000; Aanen et al., 2002), walaupun jika didasarkan pada data molekuler jumlah tersebut seharusnya lebih besar (Froslev et al., 2003). Rayap juga diketahui hanya 'bertani' fungi Termitomyces dari filum Basidiomycota dan merupakan 'petani' yang obligat (Mueller et al., 2005).

Kumbang dan kerabatnya merupakan kelompok serangga yang sering membuat lubanglubang pada kayu. Evolusi kemampuan fungiculture kumbang (terutama Ambrosia) awalnya hanya dihipotesiskan sebagai kejadian yang tidak disengaja (Batra, 1966) saat hifa dari fungi tumbuh pada saluran tersebut. Pada saat mencapai biomassa dalam jumlah cukup banyak, miselium yang bercampur bersama jaringan floem tumbuhan ikut termakan oleh kumbang. Namun belakangan juga diketahui bahwa fungi simbion kumbang ambrosia (Coleoptera : Scolytidae) merupakan fungi hidup bebas yang kemudian bergantung kepada kumbang dan berbagai kelompok Arthropoda dalam penyebaran sporanya (Mueller dan Gerardo, 2002). Genus Ambrosia merupakan kumbang pendegradasi kayu utama di daerah tropis (Hulcr dan Cognato, 2010). Mereka sepakat bahwa awal mulai evolusi fungiculture kumbang ambrosia kemungkinan 
bermula dari daerah tropis dengan suhu dan kelembapan tinggi yang merupakan kondisi pertumbuhan ideal bagi fungi dan kumbang, sehingga peluang interaksi menjadi sangat tinggi. Ketika kumbang telah menggantungkan sumber nutrisinya kepada fungi, kumbang diketahui mulai melakukan diversifikasi jenis tumbuhan untuk dilubanginya. Hal ini dikarenakan oleh kemampuan fungi untuk membantu degradasi jaringan tumbuhan (Batra, 1966). Hingga saat ini telah diketahui lebih dari 3200 spesies Ambrosia yang memiliki kemampuan 'bertani' fungi (Li et al., 2016). Pada awalnya ambrosia diduga memiliki spektrum fungi simbion yang sempit, namun penelitian terbaru menunjukkan kisaran interaksi tersebut bervariasi antar spesies dimana satu spesies Ambrosia mampu memiliki lebih dari satu asosiasi (Harrington dan Fraedrich, 2010; Carrillo et al., 2013).

Semut merupakan salah satu 'petani' terbaik fungi walaupun belum diketahui dengan jelas jalur pembentukan dan evolusi kemampuan tersebut (Mueller et al., 2001). Misteri ini kemudian menjadi sedikit terbuka ketika Schultz dan Brady (2008) berhasil mengkonstruksi pohon filogenetik (dengan model Bayesian) semut yang mendomestikasi fungi. Mereka melaporkan bahwa kemunculan dan revolusi kemampuan tersebut muncul sekitar 30 juta tahun lalu dari dataran Amerika Selatan saat terjadi perubahan dramatis pada iklim di bumi. Evolusi fungiculture tersebut berasal dari satu nenek moyang yakni semut dari kelompok Attini. Saat ini diketahui ada 6 kasta kelompok utama 'petani' semut diantaranya : 'petani' semut tingkat rendah, semut yang 'bertani' fungi koral, 'petani' khamir, 'petani' semut tingkat tinggi, 'petani' semut pemotong daun, dan satu kelompok yang belum jelas posisinya (Schultz dan Brady, 2008). Semut diketahui mencari bahan organik berupa potongan daun untuk mensuplai kebutuhan kultur fungi pada kebunnya. Kebun fungi berada di bawah tanah dan fungi terisolasi dari dunia luar. Seiring berjalannya waktu, fungi tersebut tidak bisa hidup di alam bebas, sehingga bergantung sepenuhnya pada semut (Schultz dan Brady, 2008). Disisi lain, semut menggantungkan kebutuhan nutrisinya pada hasil panen 'kebun' fungi. Saat ini sistem pertanian semut diketahui sebagai salah satu bentuk fungiculture dengan konsep pertanian berkelanjutan serta resisten terhadap patogen dan penyakit.

\section{Fungiculture Pada Semut}

Untuk waktu yang lama, sebagian besar peneliti meyakini bahwa model semut petani khamir merupakan bentuk fungiculture yang paling awal pada semut. Bahkan Sanchez-Pena (2005) sempat mengusulkan semut 'petani' fungi koral sebagai kelompok 'petani' pertama. Sebaliknya, hasil penelitian Schultz dan Brady (2008) berdasarkan konstruksi filogenetik mengkonfirmasi bahwa kelompok 'petani' semut pertama adalah 'petani' semut tingkat rendah dari kelompok Attini yang teorinya paling banyak diterima hingga saat ini. Kelompok 'petani' ini merupakan spesies parafiletik dan diketahui membudidayakan fungi Leucocoprinoid (keluarga/kerabat dari Leucopcoprinus-Basidiomycota) atau juga umum dikenal sebagai jamur parasol yang mudah ditemukan baik pada kawasan hutan alami ataupun daerah ekosistem buatan (Putra et al., 2018). Hasil penelitian lainnya (Gerardo et al., 2006) menunjukkan bahwa Escovopsis (Hypocreales, Ascomycota) juga menginfeksi substrat untuk inokulum Attini. Kelompok semut 'petani' tingkat rendah didominasi oleh genus Mycocepurus, Myrmicocrypta, dan Apterostigma (Schultz dan Brady, 2008).

Semut 'petani' fungi koral dilaporkan berasal dari genus Apterostigma. Semut ini dihipotesiskan juga mengkultivasi fungi Leucocoprinoid pada awal-awal perkembangannya. Saat 
ini, fungi koral yang banyak menjadi inokulum yang 'digunakan' oleh semut adalah famili Pterulaceae terutama genus Pterula dan Deflexula (Munkacsi et al., 2004). Bentuk ketiga dari model fungiculture semut adalah mekanisme pertanian khamir yang dilakukan oleh semut Cyphomyrmex. Berbeda dengan dua model sebelumnya yang memakai konsep 'kebun' miselium, pada yeast fungiculture khamir berada di dalam dan di luar tubuh semut. Ketika berada di dalam saluran pencernaan semut, khamir membantu degradasi berbagai material organik (Vega dan Balckwell, 2005). Sementara itu, kebun khamir umumnya terlihat sebagai koloni putih yang tersusun atas sel-sel tunggal yang terakumulasi pada substrat yang disiapkan oleh semut. Khamir yang terlibat ialah dari kelompok Cyphomyrmexrimosus (Schultz dan Brady, 2008) serta Saccharomyces (Vega dan Balckwell, 2005).

'Petani' semut tingkat tinggi dan 'petani' semut pemotong daun merupakan bentuk paling kompleks dari model simbiosis fungiculture dari kelompok semut (Gambar 1). Mereka berevolusi dari 'petani semut tingkat rendah (Schultz dan Brady, 2008) dan merupakan tingkatan paling tinggi dari kemampuan fungiculture semut yang didasarkan pada dua faktor. Pertama, kedua kelompok ini tidak mampu hidup bebas tanpa koloninya.

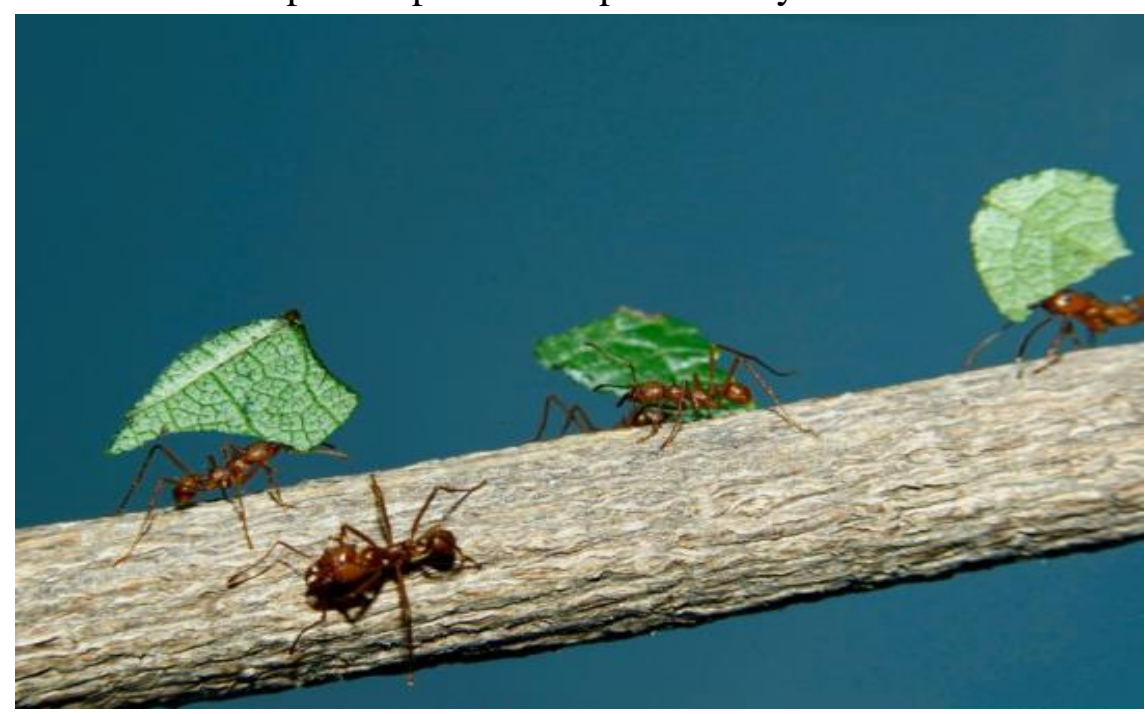

Sumber:https://www.smithsonianmag.com/science-nature/how-ants-becameworlds-best-fungus-farmers-180962871/

Gambar 1. Semut 'petani' fungi sedang mencari potongan daun untuk kebunnya.

Kedua, hanya kelompok ini yang mampu mengatur pembentukan gongylidia, modifikasi hifa fungi dimana hifa menjadi bengkak dan membesar. Hifa tersebut kemudian dimanfaatkan oleh semut sebagai sumber nutrisinya. 'Petani' semut tingkat tinggi terdiri atas dua genus yakni Sericomyrmex dan Trachymyrmex. Sementara itu semut pemotong daun terdiri atas genus Acromyrmex dan Atta. Hingga saat ini, nampaknya dapat disimpulkan bahwa 'petani' semut tingkat tinggi telah terspesialisasi menjadi 'petani' semut pemotong daun (Schultz dan Brady, 2008).

\section{Fungiculture Pada Kumbang}

Dua kelompok kumbang yang dikenal memiliki kemampuan 'bertani' fungi adalah bark beetle dan kumbang genus Ambrosia (Li et al. 2016). Namun yang paling banyak dipelajari dan dilaporkan mekanisme pertaniannya adalah kelompok ambrosia. Genus ini diketahui merupakan 
simbion obligat dari pola interkasi mutualistik dengan fungi Ascomycota dan kerabatnya. Ascomycota diketahui merupakan filum yang memiliki jenis spesies terbanyak dalam kingdom Fungi, tersebar dari kelompok yang berukuran renik hingga memiliki tubuh buah kasat mata yang berukuran besar (macrofungi). Genus-genus fungi yang berperan sebagai mikobion pada simbiosis ini diantaranya adalah Ceratocystis (pada level spesies, nama terbaru bervariasi, bisa dicek pada www.indexfungorum.org), Fusarium, Cephalosporium, Ambrosiella, Pichia, dan Hansenula (Beaver, 1989).

Salah satu karakteristik utama dari fungi pembentuk simbiosis ini adalah kemampuan pleomorfiknya (Beaver, 1989; Mueller dan Gerardo, 2002; Li et al., 2016). Sebagian besar mikobion fungi mampu tumbuh sebagai hifa, membentuk perpanjangan miselium dan mengkolonisasi substrat terutama pada saluran/lubang yang dibuat oleh kumbang. Fungi juga terkadang hanya tumbuh pada 'kebun' kumbang (Gambar 2) dengan subtrat yang telah tersedia atau bahkan pada kondisi tertentu, fungi beralih membentuk fase sel tunggal. Fungi yang tumbuh dan membentuk hifa yang keluar dari 'kebun' kumbang, mengkolonisasi jaringan xilem dan floem tumbuhan namun hanya bersporulasi pada 'kebun'nya. Umumnya hanya terdapat satu spesies fungi dominan dan bersimbiosis dengan Ambrosia, namun beberapa mikobion sekunder juga mampu tumbuh dan terkadang datang bersama dengan bakteri sehingga membuat bentuk simbiosis ini menjadi lebih kompleks (Biedermann dan Vega, 2020).

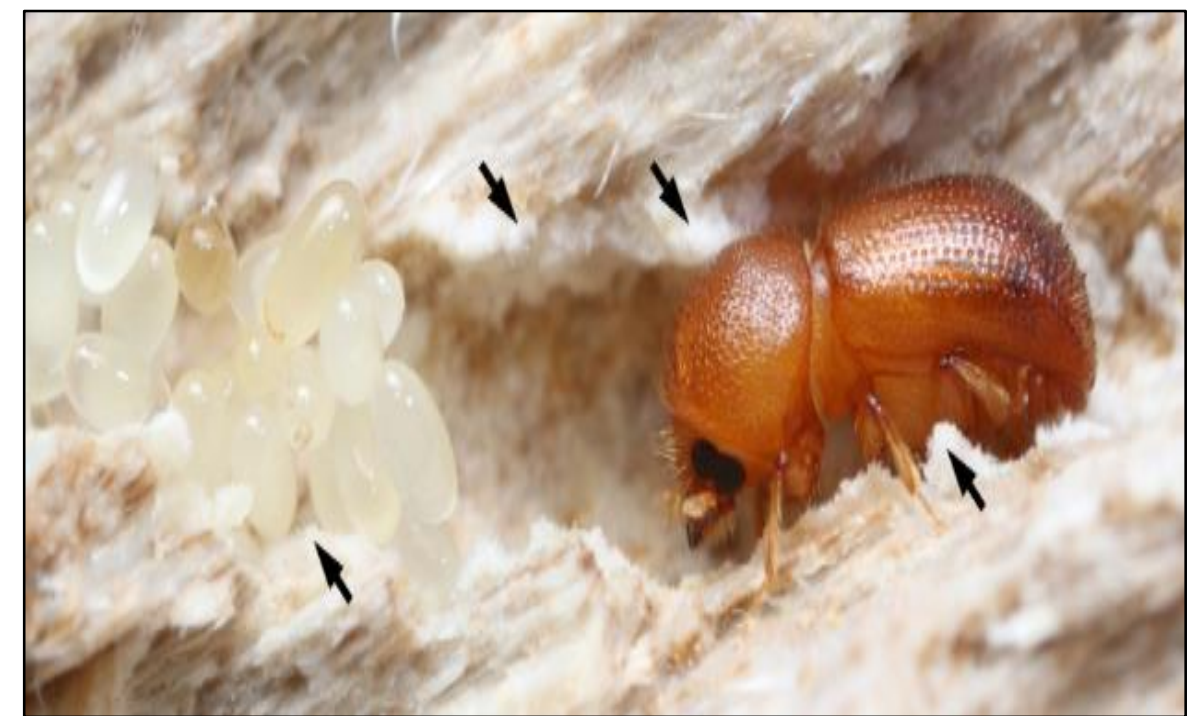

Gambar 2. Kumbang Ambrosiodmus lecontei yang bertelur pada saranggnya dipohon, tanda panah menunjukkan miselium fungi (Li et al., 2016).

Manfaat utama yang diterima fungi dari mekanisme fungiculture kumbang adalah penyebaran spora (spora dibawa pada struktur mikangia pada kumbang) dan ketersediaan tempat tumbuh yang cocok dan lembab, terutama pada saluran/lubang yang dibuat kumbang. Sementara itu dampak timbal balik yang diperoleh kumbang nampaknya lebih bervariasi (Beaver, 1989; Mueller dan Gerardo, 2002). Pertama, fungi merupakan sumber nutrisi untuk larva dan kumbang dewasa. Kedua, fungi terlibat dalam konversi komponen jaringan tumbuhan menjadi bahan feromon kumbang. Ketiga, 'inokulasi' fungi oleh kumbang membantu mereka merusak jaringan tumbuhan terutama karena fungi terlibat dalam melemahkan sistem pertahanan dan mampu menghancurkan lapisan keras jaringan tumbuhan. Hal ini membuat peluang kolonisasi dari ‘kebun' baru kumbang memiliki tingkat kesuksesan yang tinggi. 


\section{Fungiculture PadaRayap}

Sejumlah 330 dari jumlah total (lebih dari 2600) spesies rayap yang telah diketahui merupakan serangga obligat yang menggantungkan sumber makanannya dari fungi Termitomyces (Higashi et al., 2000; Eggleton, 2000; Aanen et al., 2002). Berbeda halnya dengan mekanisme 'pertanian' pada semut dan kumbang, dimana fungi jarang membentuk tubuh buah makroskopik, fungi simbion pada rayap membentuk tubuh buah hasil perkembangan reproduksi seksual fungi (plasmogami, kariogami, meiosis). Termitomyces secara berkala dikultivasi oleh rayap dan pada awalnya tumbuh pada feses rayap. Sarang rayap dibuat sedemikian rupa dengan memperhatikan suhu, kelembapan, kapasitas pertukaran gas dengan struktur ventilasi yang sesuai, sehingga memberikan lingkungan pertumbuhan yang ideal untuk fungi selama sepanjang waktu (Korb, 2003).

Fungi menjaga kesinambungan koloni rayap dengan mendekomposisi bahan organik dari tumbuhan yang telah dikumpulkan oleh rayap pekerja pada struktur comb dari sarang rayap. Selain potongan tumbuhan hasil merambah (foraging), rayap juga mensuplai bahan organik hasil dekomposisi parsial hasil pencernaannya. Proses degradasi tersebut juga dibantu oleh fungi dan enzimnya (berasal dari spora dan hifa) yang dikonsumsi oleh rayap. Hal ini memudahkan dekomposisi ligniseluloda dan berbagai macam biopolimer, yang dilakukan bersama dengan konsorsium bakteri di pencernaan rayap (Nobre dan Aanen, 2012; Poulsen et al., 2014). Semua rayap (dewasa dan larva) mendapatkan pasokan nodul-nodul kecil yang berisi spora aseksual dan atau hasil degradasi bahan organik sebagai sumber nutrisinya (Nobre dan Aanen, 2012).

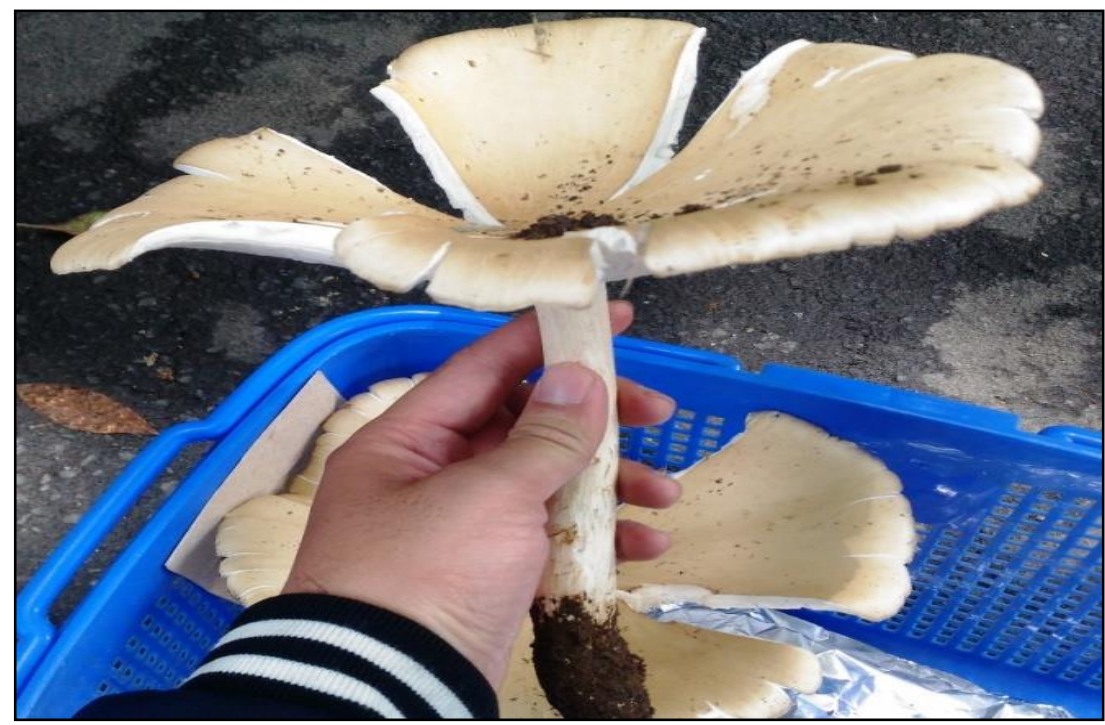

Gambar 3. Tubuh buah Termitomyces. (dokumentasi penulis)

Nenek moyang rayap yang monofiletik diketahui mengalami diversifikasi kelompokkelompok 'petani' rayap selama perkembangannya. Hal tersebut nampaknya merupakan produk interaksi 'petani' rayap dengan alam yang telah terjadi dalam jangka waktu yang lama. Saat ini, diketahui rayap yang mendomestikasi fungi memiliki relung ekologi yang beragam, mulai dari hutan tropis basah, daerah savana, hingga tempat kering (Aanen dan Eggleton, 2005). Namun, kultivar fungi tidak berubah dan tetap diwariskan dari generasi ke generasi berikutnya. Diversifikasi inokulum fungi hanya terjadi pada level spesies dari genus Termitomyces (Gambar 
3). Bentuk simbiosis ini menjadi lebih kompleks karena fungiculture pada rayap juga sering mengalami intervensi dari organisme lain seperti protista, arkea metanogen, dan bakteri (Bignell, 2000).

\section{Manajemen 'Kebun Fungi'}

Keberlangsungan dan kondisi harmoni simbiosis pada mekanisme fungiculture serangga umumnya ditentukan oleh beberapa hal. Pertama, kerjasama yang baik dan manfaat mutualistik dua arah merupakan hal utama dalam keberlanjutan simbiosis. Pada kelompok 'petani' serangga dan fungi yang telah teradaptasi menjadi simbion yang obligat, mekanisme transfer propagul fungi secara vertikal antar generasi merupakan cara yang dilakukan untuk menjamin kondisi homeostasis 'kebun' fungi pada generasi berikutnya. Namun demikian pada beberapa kasus, transfer inokulum secara horizontal antar sarang juga terjadi (Skelton et al., 2019). Kedua, mekanisme 'sanksi' diberlakukan pada simbion yang tidak menjalankan perannya, misal: fungi tidak tumbuh pada substrat yang telah disiapkan namun berusaha untuk membentuk struktur reproduksi seksual dan memindahkkan sporanya sendiri secara horizontal (Mehdiabadi et al., 2006). Ketiga, mekanisme kontrol terhadap organisme pengganggu 'kebun' serangga diperlukan untuk menjaga kesehatan sistem pertanian yang akan dijelaskan pada paragraf berikutnya.

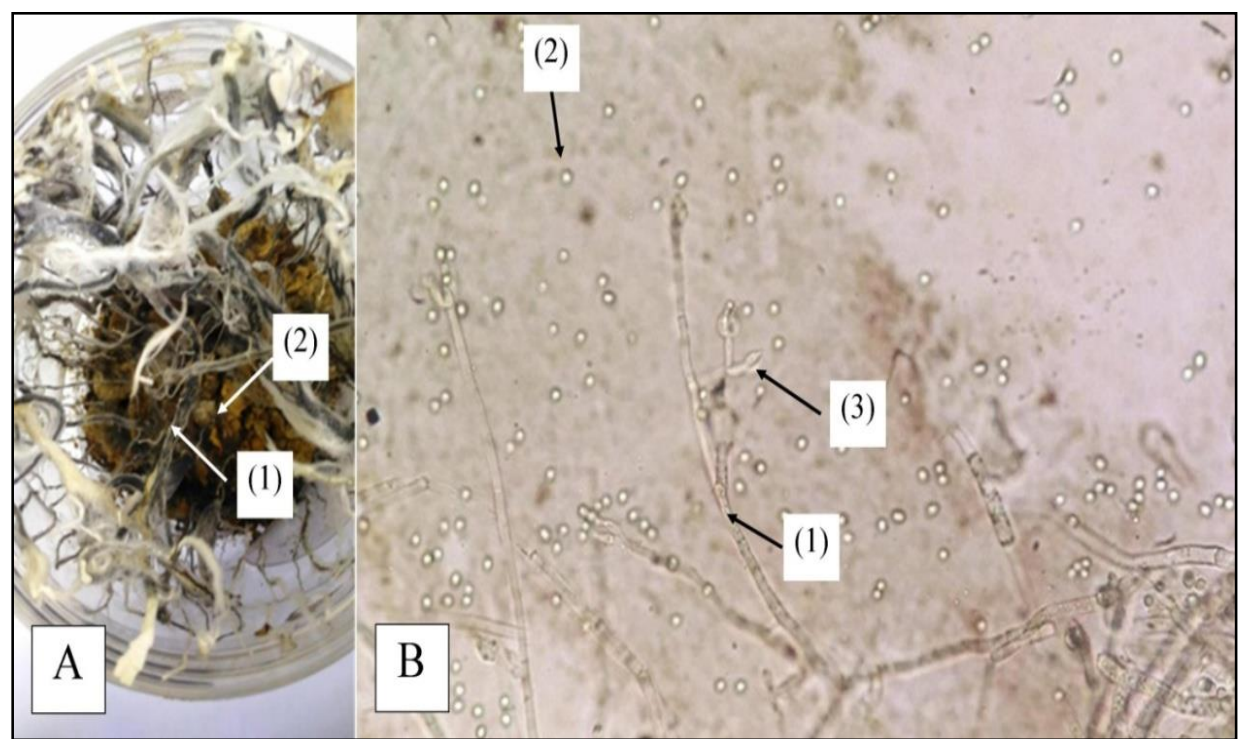

Gambar 4. A. Pseudoxylaria (1)dan Trichoderma (2) yang tumbuh pada sarang rayap. B. Karakter mikroskopik Trichoderma di bawah mikroskop, (1) konidiofor, (2) konidia yang telah lepas dari konodiogen, (3) sel konidiogen / fialid. Perbesaran 400x. (Dokumentasi penulis)

Ketiga serangga yang telah dibahas sebelumnya merupakan 'petani' fungi yang handal. Mereka menjaga dan mengontrol pertumbuhan fungi serta mengeliminasi pertumbuhan fungi parasit, tungau, nematoda, ataupun kontaminan lainnya pada 'kebunnya'. Pada rayap, ketidakhadiran rayap pekerja dan rayap tentara menyebabkan munculnya fungi kontaminan dan fungi antagonistik seperti Pseudoxylaria (Gambar 4. A) dan Trichoderma (Gambar 4. A dan B) yang menyebabkan deteriorasi pada sarang dan 'kebun' rayap (Visser et al., 2011; Otani et al., 2019). Hal ini mengindikasikan peranan penting pemeliharaan 'kebun' oleh rayap. Rayap memaksimalkan beberapa strategi pemeliharaan 'kebun' diantaranya dengan mengubur fungi pengganggu yang tumbuh (Katariya et al., 2017; Katariya et al., 2018) ataupun memanfaatkan 
simbion bakterinya (Bacillus) untuk menghasilkan bahan antibiotik yang efektif terhadap fungi patogen (Um et al., 2013). Bodawatta et al., (2019) melaporkan bahwa saat merambah, rayap pekerja juga mampu memilah material tumbuhan yang mengandung entomopatogen (fungi patogen serangga) dan mikopatogen (fungi patogen pada fungi lainnya) yang difasilitasi oleh perangkat indera penciumannya (Mburu et al., 2009).

Pada 'kebun' semut masalah utama yang dihadapi adalah invasi fungi Escovopsis yang menyebabkan kerusakan pada sistem pertanian semut dan mengganggu pertumbuhan inokulum fungi yang sedang diwarat. Pada banyak koloninya, semut mengembangkan strategi membuat 'jaket' fungi atau bakteri yang melingkupi tubuhnya untuk menekan pertumbuhan mikroorganisme pengganggu termasuk tungau, nematoda, dan berbagai macam penyebab penyakit lainnya (Mueller et al., 2010; Pousen et al., 2002). Jaket ini memiliki efek 'pestisida' antimikrobial yang ampuh untuk menjaga kesehatan sarang dan 'kebun' fungi. Bakteri yang digunakan untuk membuat 'jaket' semut tersebut diketahui berasal dari genus Streptomyces, kelompok yang banyak dimanfaatkan dalam bidang medis dan farmasi oleh manusia. Mekanisme proteksi lainnya ialah pemindahan inokulum beserta substrat yang telah terkontaminasi pada tempat khusus yang telah disiapkan oleh semut pekerja. Tempat yang dipilih umumnya memiliki suhu yang cukup tinggi untuk menginisiasi proses desikasi (Cremer dan Kutzer, 2019).

Pada sistem pertanian kumbang Ambrosia, serangga simbion mengurangi fluktuasi perubahan lingkungan dan serangan organisme pengganggu (fungi patogen, bakteri, tungau dan berbagai penyakit) salah satunya dengan membangun barrier pada saluran/lubang tempat tinggalnya (Kirkendall et al., 2015). Saluran dan barikade yang dibuat juga dilaporkan sebagai salah satu upaya proteksi kumbang terhadap 'mycocleptism', yakni kemampuan kumbang lain yang bukan merupakan bagian dari koloni untuk 'mencuri' inokulum fungi dan digunakan pada 'kebun'nya sendiri (Hulcr dan Cognato, 2010). Selain itu, pada awal-awal pencarian lokasi untuk pembuatan 'kebun', kumbang dilaporkan mencari jaringan tumbuhan yang mengeluarkan senyawa volatil seperti etanol. Bahan ini diketahui mampu untuk memacu pertumbuhan fungi simbion kumbang dan nampaknya mampu menghambat pertumbuhan fungi kontaminan yang tidak dikehendaki (Dao dan Dantigny, 2011). Namun, pada kondisi tertentu barikade yang dibuat tidak mampu untuk mencegah invasi dari kapang seperti Fusarium, Aspergillus, Paecilomyces, dan Penicillium. Seperti halnya fungi lainnya, patogen ini memiliki tempat hidup yang kosmopolitan dan mampu tersebar pada daya jelajah yang luas.

\section{KESIMPULAN}

Sejarah panjang evolusi dan pengembangan strategi pertanian serangga dalam mengatasi berbagai kondisi,menggambarkan hubungan simbiosis harmoni yang masih berlangsung hingga saat ini. Kemampuan 'bertani' yang dimiliki oleh rayap, kumbang, dan semut merupakan produk interaksi antara serangga dan fungi yang dipengaruhi oleh kondisi lingkungan. Adanya keselarasan dan kerjasama yang mumpuni antara serangga simbion dan mikobion merupakan kunci kesuksesan sistem pertanian fungi oleh serangga. Serangga diketahui mengembangkan strategi kultivasi fungi meliputi pembagian kerja antar anggota koloninya : mulai dari penyiapan inokulum fungi, perawatan, proteksi dari patogen dan hama pengganggu, hingga pemanenan. 
Sebagai negara yang menyimpan keragaman serangga dan fungi yang tinggi, penelitian terkait 'kebun' fungi oleh serangga di Indonesia tentunya memiliki peluang untuk mengungkap hal-hal baru yang belum pernah dilaporkan sebelumnya.

\section{REFERENSI}

Aanen, D. K., Eggleton, P., Rouland-Lefevre, C., Guldberg-Froslev, T., Rosendahl, S., and Boomsma, J. J. 2002.The evolution of fungus-growing termites and their mutualistic fungal symbionts. Proceedings of the National Academy of Sciences, 99(23):14887-14892. http://dx.doi.org/10.1073/pnas.222313099.

Aanen, D.K., and Eggleton, P. 2005. Fungus-Growing Termites Originated in African Rain Forest. Current Biology, 15(9):851-855. http://dx.doi.org/10.1016/j.cub.2005.03.043.

Anwar, K., Sudirman, L.I., and Nandika, D.2020. Comb Establishment of fungus-growing termites species Macrotermitinae (Isoptera: Termitidae) with Termitomyces cylindricus (Basidiomycota: Agaricales) basidiospores. Oriental Insects. http://dx.doi.org/10.1080/ 00305316.2020.1762775.

Batra, L.R. 1966. Ambrosia Fungi: Extent of Specificity to Ambrosia Beetles. Science, 153(3732):193-195. http://dx.doi.org/10.1126/science.153.3732.193.

Beaver, R.A. 1989. Insect-Fungus Relationships in the Bark and Ambrosia Beetles. Insectfungus Interactions, 14: 121-143. http://dx.doi.org/10.1016/b978-0-12-751800-8.50011-2.

Biedermann, P.H.W., and Vega, F.E. 2020. Ecology and Evolution of Insect-Fungus Mutualisms. Annual Review of Entomology, 65(1):431-455. http://dx.doi.org/10.1146/annurev-ento-011019-024910.

Bodawatta, K., Poulsen, M., and Bos, N. 2019. Foraging Macrotermes natalensis FungusGrowing Termites Avoid a Mycopathogen but Not an Entomopathogen. Insects, 10(7): 185-193.http://dx.doi.org/10.3390/insects10070185.

Bignell, D.E. 2000. Introduction to symbiosis.(In): Abe T., Bignell D.E., Higashi M. (eds) Termites: Evolution, Sociality, Symbioses, Ecology. Springer, Dordrecht.pp.189-208. http://dx.doi.org/10.1007/978-94-017-3223-9_9.

Bourke, A. F. G. 2005. Genetics, relatedness and social behaviour in insect societies. Insect Evolutionary Ecology: Proceedings of the Royal Entomological Society's 22nd Symposium, Reading, UK, 2003, 1-30. http://dx.doi.org/10.1079/9780851998121.0001.

Carrillo, D., Duncan, R. E., Ploetz, J. N., Campbell, A. F., Ploetz, R. C., and Peña, J. E. 2013. Lateral transfer of a phytopathogenic symbiont among native and exotic ambrosia beetles. Plant Pathology, 63(1): 54-62. http://dx.doi.org/10.1111/ppa.12073.

Cremer, S., Abe,T, and Kutzer, M.A.M. 2019. Social Immunity. (In) : Encyclopedia of Animal Behavior. Academic Press, Austria. pp747-755. http://dx.doi.org/10.1016/b978-0-12809633-8.90721-0.

Chang, S.T., and Miles, P. 2004. Mushrooms : cultivation, nutritional value, medicinal effect, and enviromental impact $2^{\text {nd }}$ edition.NewYork, CRS Press.pp477.

Currie, C.R., Wong, B., Stuart, A.E., Schultz, T.R., Rehner, S.A., Mueller, U.G., Sung, G.H., Spatafora, J.W., and Neil, A.S. 2003. Ancient tripartite coevolutionin the attine antmicrobe symbiosis. Science, 299:386-388.http://dx.doi.org/10.1126/science.1078155. 
Dao, T., and Dantigny, P. 2011. Control of food spoilage fungi by ethanol. Food Control, 22 (34):360-368. http://dx.doi.org/10.1016/j.foodcont.2010.09.019.

Eggleton, P. 2000. Global Patterns of Termite Diversity. In: Abe T., Bignell D.E., Higashi M. (Eds) Termites: Evolution, Sociality, Symbioses, Ecology. Springer, Dordrecht.pp.25-51. http://dx.doi.org/10.1007/978-94-017-3223-9_2.

Farrel1, B. D., Sequeira, A. S., O’Meara, B. C., Normark, B. B., Chung, J. H., andJordal, B. H. 2001. The evolution of agriculture in beetles (Curculionidae: Scolytinae and Platypodinae). Evolution, 55(10): 2011-2027. http://dx.doi.org/10.1111/j.0014-3820.2001.tb01318.x.

Foster, K. R., and Wenseleers, T. 2006. A general model for the evolution of mutualisms.Journal of Evolutionary Biology, 19(4): 1283-1293. http://dx.doi.org/10.1111/j.14209101.2005.01073.x.

Froslev, T. G., Aanen, D. K., Laessøe, T., and Rosendahl, S. 2003.Phylogenetic relationships of Termitomyces and related taxa.Mycological Research, 107(11):1277-1286. http://dx.doi.org/10.1017/s0953756203008670.

Gerardo, N.M., Mueller, U.G.,and Currie, C.R.2006. Complex host-pathogen coevolution in the Apterostigma fungus-growing ant-microbe symbiosis.BMC Evolutionary Biology, 6(1):88. http://dx.doi.org/10.1186/1471-2148-6-88.

Harrington, T. C., and Fraedrich, S. W. 2010.Quantification of Propagules of the Laurel Wilt Fungus and Other Mycangial Fungi from the Redbay Ambrosia Beetle, Xyleborus glabratus. Phytopathology, 100(10):1118-1123. http://dx.doi.org/10.1094/phyto-01-100032.

Higashi, M., Bignell, D.E. and Abe, T. 2000. Theories on the sociality of termites. (In): Abe T., Bignell D.E., Higashi M. (eds) Termites: Evolution, Sociality, Symbioses, Ecology. Springer, Dordrecht, pp466.http://dx.doi.org/10.1007/978-94-017-3223-9.

Hulcr, J., and Cognato, A.I.2010. Repeated evolution of crop theft in fungus-farming ambrosia beetles. Evolution, 64(11):3205-3212. http://dx.doi.org/10.1111/j.1558-5646.2010.01055.x

Katariya, L., Ramesh, P. B., Gopalappa, T., Desireddy, S., Bessière, J.M., and Borges, R. M. 2017. Fungus-Farming Termites Selectively Bury Weedy Fungi that Smell Different from Crop Fungi. Journal of Chemical Ecology, 43(10): 986-995. http://dx.doi.org/10.1007/s10886-017-0902-4.

Katariya, L., Ramesh, P. B., Sharma, A., and Borges, R. M. 2018. Local hypoxia generated by live burial is effective in weed control within termite fungus farms. Insectes Sociaux, 65(4): 561-569. http://dx.doi.org/10.1007/s00040-018-0644-5.

Kirkendall, L.R., Biedermann, P.H.W., and Jordal, B.H.2015. Evolution and Diversity of Bark and Ambrosia Beetles. In Bark Beetles. Academic Press, US,pp 85-156. http://dx.doi.org/10.1016/b978-0-12-417156-5.00003-4.

Korb, J. 2003. Thermoregulation and ventilation of termite mounds.Naturwissenschaften, 90(5): 212-219. http://dx.doi.org/10.1007/s00114-002-0401-4.

Li, Y., Simmons, D. R., Bateman, C. C., Short, D. P. G., Kasson, M. T., Rabaglia, R. J., and Hulcr, J. 2016. Correction: New Fungus-Insect Symbiosis: Culturing, Molecular, and Histological Methods Determine Saprophytic Polyporales Mutualists of Ambrosiodmus Ambrosia Beetles. Plos One, 10(9), 1-13. http://dx.doi.org/10.1371/journal.pone.0147305. 
Mburu, D. M., Ochola, L., Maniania, N. K., Njagi, P. G. N., Gitonga, L. M., Ndung’u, M. W., and Hassanali, A. 2009. Relationship between virulence and repellency of entomopathogenic isolates of Metarhizium anisopliae and Beauveria bassiana to the termite Macrotermes michaelseni. Journal of Insect Physiology, 55(9): 774-780. http://dx.doi.org/10.1016/j.jinsphys.2009.04.015.

Mehdiabadi, N.J., Hughes, B. and Mueller, U.G. 2006. Cooperation, conflict, and coevolution in the attine ant-fungus symbiosis. Behavioral Ecology, 17(2):291-296. http://dx.doi.org/10.1093/beheco/arj028.

Merritt, J.F.2010.The biology of small mammals.The Johns Hopkins University Press, Baltimore. pp313.

Mueller, U. G., Schultz, T. R., Currie, C. R., and Malloch, D. 2001. The Origin of the Attine Ant-Fungus Mutualism. The Quarterly Review of Biology, 76(2): 169-197. http://dx.doi.org/10.1086/393867.

Mueller, U. G., and Gerardo, N. 2002. Fungus-farming insects: Multiple origins and diverse evolutionary histories. Proceedings of the National Academy of Sciences, 99(24): 1524715249. http://dx.doi.org/10.1073/pnas.242594799.

Mueller, U.G, Gerardo, N.M, Aanen, D.K, Six D.L, and Schultz, T.R.2005. The evolution of agriculture in insects.AnnuRev EcolEvolSyst 36: 563-595.

Mueller, U.G., Ortiz, A. and Bacci, M. 2010. Planting of fungus onto hibernating workers of the fungus-growing ant Mycetosoritis clorindae (Attini, Formicidae). Insectes Sociaux, 57(2):209-215. http://dx.doi.org/10.1007/s00040-010-0072-7.

Munkacsi, A. B., Pan, J. J., Villesen, P., Mueller, U. G., Blackwell, M., and McLaughlin, D. J. 2004. Convergent coevolution in the domestication of coral mushrooms by fungusgrowing ants. Proceedings of the Royal Society of London. Series B: Biological Sciences, 271(1550): 1777-1782. http://dx.doi.org/10.1098/rspb.2004.2759.

Nobre, T., and Aanen, D.K. 2012.Fungiculture or Termite Husbandry?The Ruminant Hypothesis.Insects, 3(1): 307-323. http://dx.doi.org/10.3390/insects3010307.

Otani, S., Challinor, V. L., Kreuzenbeck, N. B., Kildgaard, S., Krath Christensen, S., Larsen, L. L. M., and Poulsen, M. 2019. Disease-free monoculture farming by fungus-growing termites.Scientific Reports, 9(8819):1-10. http://dx.doi.org/10.1038/s41598-019-45364-z.

Poulsen, M., Bot, A. N. M., Currie, C. R., andBoomsma, J. J. 2002. Mutualistic bacteria and a possible trade-off between alternative defence mechanisms in Acromyrmex leaf-cutting ants. Insectes Sociaux, 49(1): 15-19. http://dx.doi.org/10.1007/s00040-002-8271-5.

Poulsen, M., Hu, H., Li, C., Chen, Z., Xu, L., Otani, S., and Zhang, G. 2014. Complementary symbiont contributions to plant decomposition in a fungus-farming termite.Proceedings of the National Academy of Sciences, 111(40): 14500-14505. http://dx.doi.org/10.1073/pnas. 1319718111.

Putra, I.P., Sitompul, R. dan Chalisya, N.2018. Ragam dan potensi jamur makro asal Taman Wisata Mekarsari Jawa Barat. Al-Kauniyah: Jurnal Biologi, 11(2):133-150. http://dx.doi.org/10.15408/kauniyah.v11i2.6729.

Putra, I. P., Amelya, M. P., Nugraha, N. H., dan Zamia, H. Z. 2019. Catatan Beberapa Jamur Makro di Hutan Kampus Institut Pertanian Bogor. Biota, 12(2): 57-71. http://dx.doi.org/10.20414/jb.v12i2.192. 
Putra, I.P. 2020.Record On Macroscopic Fungi At IPB University Campus Forest : Description And Potential Utilization. IJOSE, 4(1):1-11.

Rouland-Lefèvre, C. 2000. Symbiosis With Fungi. In: Abe T., Bignell D.E., Higashi M. (Eds) Termites: Evolution, Sociality, Symbioses, Ecology. Springer, Dordrecht. pp289-306. http://dx.doi.org/10.1007/978-94-017-3223-914.

Sanchez-Pena, S.R. 2005. New view on origin of attine ant-fungus mutualism: Exploitation of a prexisting insect-fungus symbiosis (Hymenoptera: Formicidae). Ann EntomolSoc Am, 98:151-164.

Schultz, T. R., and Brady, S. G. 2008. Major evolutionary transitions in ant agriculture. Proceedings of the National Academy of Sciences, 105(14): 5435-5440. http://dx.doi.org/10.1073/pnas.0711024105.

Skelton, J., Johnson, A. J., Jusino, M. A., Bateman, C. C., Li, Y., andHulcr, J. 2019. A selective fungal transport organ (mycangium) maintains coarse phylogenetic congruence between fungus-farming ambrosia beetles and their symbionts. Proceedings of the Royal Society B: Biological Sciences, 286(1894): 2018-2127. http://dx.doi.org/10.1098/rspb.2018.2127.

Um, S., Fraimout, A., Sapountzis, P., Oh, D.C., andPoulsen, M. 2013. The fungus-growing termite Macrotermes natalensis harbors bacillaene-producing Bacillus sp. that inhibit potentially antagonistic fungi. Scientific Reports, 3, 3250: 1-7. http://dx.doi.org/10.1038/ srep03250.

Vega, F., and Blackwell, M. 2005. Insect-Fungal Associations: Ecology and Evolution. Oxford University Press, Oxford and New York. pp352.

Visser, A. A., Kooij, P. W., Debets, A. J. M., Kuyper, T. W., andAanen, D. K. 2011. Pseudoxylaria as stowaway of the fungus-growing termite nest: Interaction asymmetry between Pseudoxylaria, Termitomyces and free-living relatives. Fungal Ecology, 4(5): 322-332. http://dx.doi.org/10.1016/j.funeco.2011.05.003.

\section{Authors:}

Ivan Permana Putra, Divisi Mikologi, Departemen Biologi, Fakultas Matematika dan Ilmu Pengetahuan Alam, IPB University, Gedung Biologi, Kampus IPB Dramaga, Babakan, Dramaga, Bogor, Jawa Barat, 16680, Indonesia, email: ivanpermanaputra@apps.ipb.ac.id

This is an open-access article distributed under the terms of the Creative Commons Attribution License, which permits unrestricted use, distribution and reproduction in any medium, provided the original author and source are credited. (http://creativecommons.org/licenses/by/4.0/).

\section{How to cite this article:}

Putra, I. P. 2020. Fungiculture: Insect farming fungi. Simbiosa, 9(1):77-89. Doi. http://dx.doi.org/10.33373/simbio.v9i1.2468 